\title{
NON-DESTRUCTIVE GPR ANALYSIS OF THREATENED ANGKORIAN CERAMIC KILNS AT BANGKONG, SIEM REAP, CAMBODIA
}

\author{
Till F. SONNEMANN ${ }^{1} \&$ Rachna CHHAY ${ }^{2}$ \\ ${ }^{1}$ Leiden University (The Netherlands), ${ }^{2}$ APSARA Authority (Cambodia) \\ Corresponding author: t.f.sonnemann@arch.leidenuniv.nl) \\ Key Words: kiln, ceramics, Cambodia, Angkor, geophysics, GPR, heritage conservation
}

\begin{abstract}
Pedestrian surveys have identified a large number of 9 th century ceramic kilns to the north of the early Angkorian centre of Hariharalaya. Recent development in this area has put this archaeological site under threat. With a large number of kilns already destroyed before analysis, it was necessary to identify the sites for protection from further damage.

Since the defined areas showed little evidence on the surface, GPR surveys were conducted to find out what additional subsurface features could be used for classification. Using a $250 \mathrm{MHz}$ antenna system, the surveys were conducted over four kilns in varying state of preservation. The analysis included one definite and partly exposed kiln, and three potential kilns. Of the latter, one had been completely bulldozed, one partly destroyed and another one had remained undisturbed.

The geophysical surveys shows the possibilities to better define the extent of the kiln mound. $3 D$ visualization of the data displays depth and extent of the fire box and ware chamber of this type of Khmer kiln, providing the opportunity to better outline the area to be protected. The survey serves as a successful sample case for the systematic non-destructive mapping of known and newly discovered kiln sites.
\end{abstract}

\section{INTRODUCTION}

The village of Bangkong is located on the banks of the Roluos River, about $20 \mathrm{~km}$ to the east of Siem Reap, the gateway to the major temples of Angkor, Angkor Wat and Angkor Thom. Pedestrian survey defined the area around the Bangkong village as an important ceramic production site of this medieval Khmer capital. The kiln site is situated on an alluvial plain alongside a small river. The kilns are either very shallow mounds or completely flat surfaces covered by ceramic scatter and little vegetation, therefore difficult to distinguish from their surroundings. On the opposite side of the Roluos River (the entry to the developed site is at $389982 \mathrm{E}, 1479938$ N, WGS84, UTM Zone 48N) 37 potential kilns were identified in an area of approximately $1500 \mathrm{~m} \times 500 \mathrm{~m}$, now known as Bangkong kiln site, (also referred to as Vakan or Bakaong or Bankaong, Tabata 2007: 63). The sheer number and dense concentration of kilns shows that Bangkong once was an important ceramic production site. Radiocarbon dates from recent archaeological excavation has identified its time of operation as contemporary to the early-Angkorian capital of Hariharalaya (sometimes referred to as Hariharalayapura), which lies $5 \mathrm{~km}$ to the south on the same stream, its temple enclosures today known as the Roluos Group (see Figure 1).

In 2007 it was discovered that several kilns had been demolished by new landowners, leaving less than half of the kilns in good condition, while a large number had been either partly damaged or completely destroyed. This led to a large-scale investigation by APSARA, the Authority for the Protection and Management of Angkor and the Region of Siem Reap. Pre-empting the complete destruction of the kilns, ground surveys were conducted to establish a site inventory regarding their location and condition and clarify their time of use. Targeted excavations were carried out as well to understand the kiln structure and recover ceramic samples.

As part of this operation, four of the southern-most kilns, under direct risk of destruction, were investigated using ground-penetrating radar (GPR). Each of the sites was chosen for its state of conservation. The intent of the GPR survey was to provide additional evidence to the surface scatter of ceramic sherds, to clarify that these sites had once been kilns. Building on earlier successful GPR surveys, the plan incorporated mapping soil changes that could determine the extent of the mound, and measure the extent and depth of any fire box and ware chamber.

Considering the advantage that fast and nondestructive geophysical prospection holds for analysing archaeological sites, geophysics is still underrepresented in the investigation of Cambodia's past. GPR surveys at Angkor, targeting a wide number of archaeological issues through the years 2007-2012 have been successful regarding the water management (Sonnemann 2012a), buiding remains (Sonnemann 2012a), furnaces (Hendrickson et al. in press), and state the necessity for a geophysical data base (Sonnemann in press). One of the surveys concerns the analysis of ceramic kilns (an overview can be found in Sonnemann 2011).

This paper gives a brief summary on the archaeological work on Khmer kilns and introduces the methods 


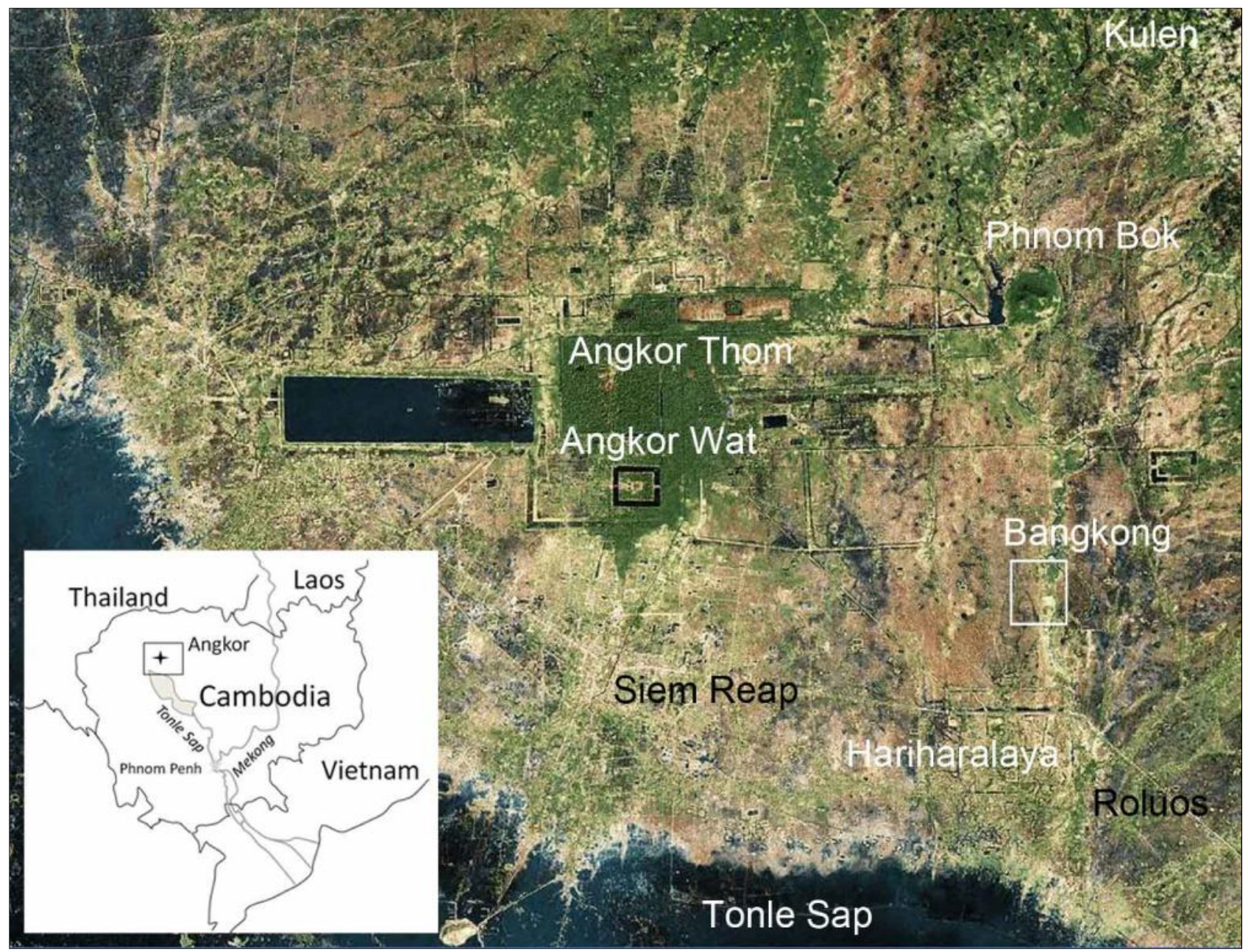

Figure 1: The location of Bankong Kiln Site in regards to Angkor (Image Source: Microsoft Bing).

applied, demonstrating the possibility of GPR surveys to determine a number of characteristics of Cambodian kilns.

\section{RESEARCH ON KHMER KILNS}

The study of ceramic kilns has provided important information on the development of the medieval Khmer culture in Cambodia. Ceramic sherd concentrations are evidence for settlements in the Angkor region; their classification serves to distinguish periods of occupation and decay. Kilns store extensive quantities of ceramics of the same time period. Their analysis has improved historic knowledge on Angkorian ceramic typology and chronology, and shed light on the process of production.

Khmer kiln sites at Anlong in the Kulen Hills to the northeast of Angkor were mentioned as early as 1901 by Aymonier (1901: 414). Khmer ceramics has been studied intensively, e.g. Brown 1973; Brown 1977; Groslier 1981; Rooney 1984; Desbat 2011) for a long period mainly focussed on ceramic objects from excavations. Due to the political situation in Cambodia in the 1970s - until the beginning of the 1990s, research on Angkorian kiln sites was initially conducted in Thailand
(Silapakorn 1989; Guy 1989: 15; Barbetti and Hein 1998). In Cambodia the investigation of kilns was begun by Sophia University (Japan) in the 1990s, in collaboration with the Cambodian APSARA Authority (Aoyagi et al. 2000: 235-253). More recent excavations of Khmer kilns at Thnal Mrech, also known as Anlong Thom (Miksic et al. 2009; Tabata 2008) in the Kulen Hills have unearthed a large quantity of ceramic material. With the application of modern analytic techniques, elemental analysis of the material and radiocarbon dating, the studies have provided clues to the process of ceramic production, and have shed new light on the chronological order of Khmer ceramic sequences, and the development of Khmer culture (Darith 2010: 220).

In 1996, two kilns at Tani, located $40 \mathrm{~km}$ northeast of the centre of Angkor near the Kulen hills, were surveyed using geophysical techniques: magnetometry as well as GPR (Aoyagi et al. 2000) conducted by Nabunken Institute, Japan (Nishimura 2000, Nabunken 2001). Their magnetometry data shows the strong anomaly that defines a kiln site, while the GPR shows extent and structure of the fire box under the kiln mound, which indicated a successful outcome of the following study. 

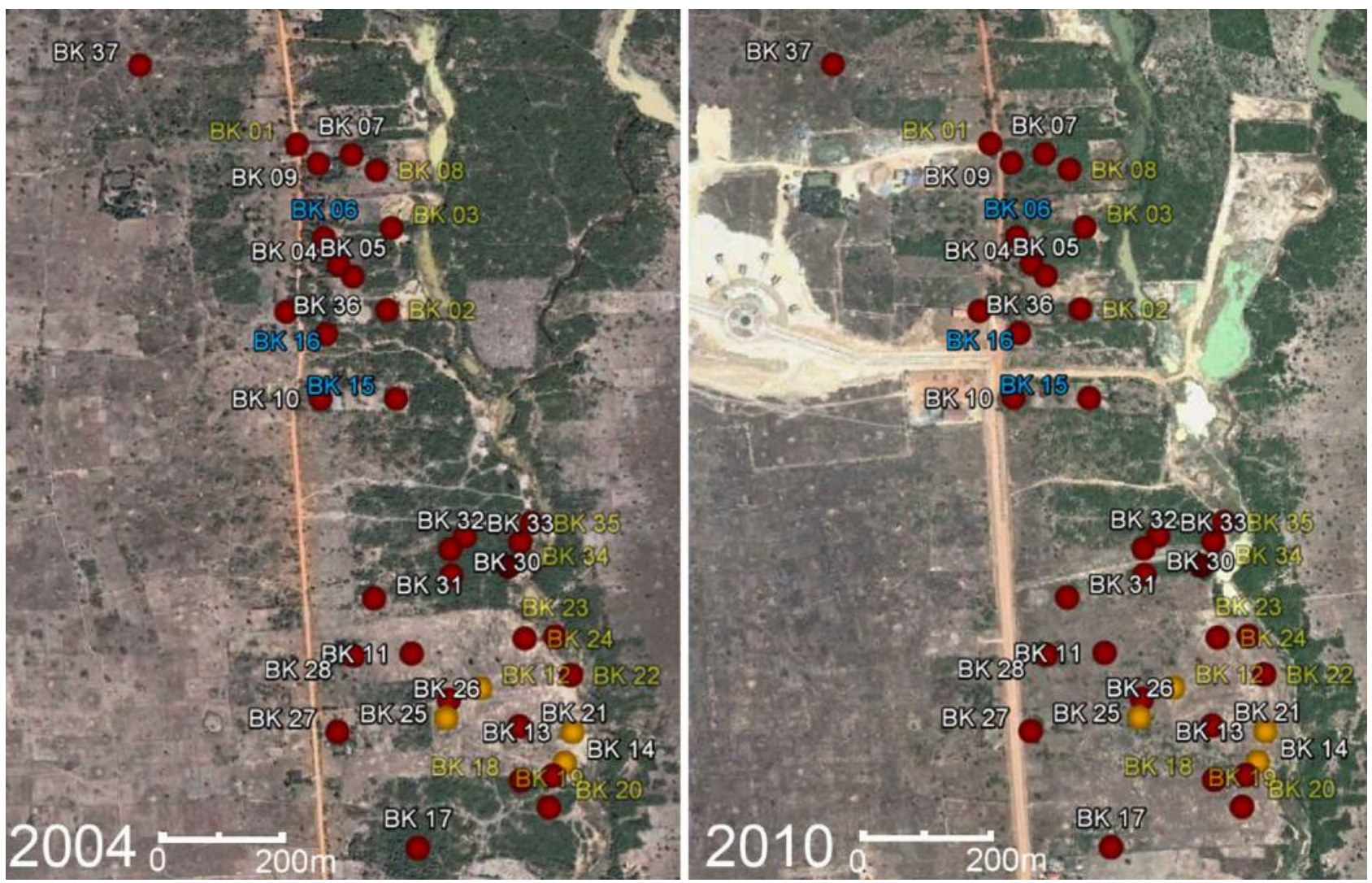

Figure 2: Remote sensing image of the area with identified kilns, in 2004 and 2013. The investgated kilns are marked in yellow. (Image Source: Google Earth)

\section{The Bangkong Kiln Site}

The Bangkong kiln site was discovered in 1995 when a road alongside Roluos River was widened, and a bulldozer cut through one of the kilns (pers. com. Christophe Pottier, who investigated the site in 1998). When a survey by APSARA personnel in 2005 investigated the area again, several other kilns were discovered. The following remote sensing and field walking campaign has mapped so far a total of 37 kiln sites (Miksic and Chhay 2010: 11). They have been catalogued as BK01 to BK37, according to their discovery, and were included in APSARA's GIS of archaeologically relevant sites (Table 1).

Table 1: Overview of work activity at Bangkong kiln site.

\begin{tabular}{ll}
\hline Year & Archaeological research activity at Bangkong kiln site \\
\hline 1995 & Site discovered \\
1998 & Site surveyed by C. Pottier \\
2005 & Preliminary site survey by APSARA personnel \\
$2007-$ & Remote sensing \& field walking campaign by R. Chhay \\
2009 & \\
Jan. & Excavation \& dating by Osaka-Ohtani/APSARA \\
2008 & \\
Dec. & GPR survey by T.F. Sonnemann and R. Chhay \\
2008 & \\
Nov. & Planned test pits \\
2014 & \\
\hline
\end{tabular}

Five kilometres further south, King Indravarman I established in the $8-9^{\text {th }}$ century his political centre Hari- haralaya at at the fertile but bi-annually fluctuating shore line of the Tonle Sap lake (Jacques and Freeman 1997: 62). To have a constantly running water source, a river was partially diverted at the hill of Phnom Bok and directed south. The channelled stream, today known as Roluos River, became the main water source for the early Angkorian capital, which remained an important secondary centre when, in the $9^{\text {th }}$ century, a new capital was built to the northwest in the Angkor area (Penny et al. 2006). The reliable supply of water may have been the reason for establishing the ceramic production at Bangkong.

The kilns at Bangkong differ strongly in appearance from other Angkorian kilns. They are barely raised above the ground, compared to the several meter high mounds of Tani. The ware chamber of these kilns may have been dug into the sandy soils of the former river bank. Many kilns are only evident due to an increased ceramic distribution on site, or a change to a lighter soil colour. Less vegetation indicates a dried and hardened clay surface at a number of sites.

In conjunction with Osaka-Ohtani University, the APSARA's Department of Preventative Archaeology performed a rescue excavation of kilns BK15 and BK16 in January 2008 (Darith 2010: 25) to salvage some of the ceramic material (Miksic and Chhay 2010: 11). The excavation demonstrated that the majority of the kilns were used to produce stone ware. Only BK16, a kiln structure fired at very low temperature, possibly pro- 
duced earthenware. However, as their form is similar to the analysed stoneware, there is a possibility that the ceramic associated with the kiln is underfired stoneware (Chhay 2009). AMS radiocarbon dating from charcoal samples of kiln BK15 (1107 \pm 20 BP) and BK06 (1214 $\pm 23 \mathrm{BP})$ produced dates of the mid- $8^{\text {th }}$ to the end of the $10^{\text {th }}$ century (Miksic and Chhay 2010: 11, APSARA Authority 2010: 14, Osaka Ohtani University 2011: 78). Thus the Bangkong archaeological site represents some of the oldest kilns in the Angkor region identified to present day.

\section{Kiln site under threat}

The kilns are located in the second protection zone of the Angkor Archaeological Park, a UNESCO World Heritage site. In the 1990 s, when other kiln sites were heavily looted (Miksic and Chhay 2010: 8), the Bangkong kilns may have been over looked due to their particular characteristics, blending into the landscape. However, the progression of development plans of the Siem Reap provincial government has advanced large scale construction close to the site. Land has been bought by new owners, who try to increase the property value by flattening the small mounds found on their land. A drainage canal was dug through the kiln area to avoid flooding of the new development zone (Chhay 2009). In addition, the Roluos River sand deposits provide easily accessible building material for the booming Siem Reap town. At the time of the survey, field mapping by Chhay indicated that of 37 kilns discovered (see Figure 2), only 17 were in good condition, while the other kilns had been damaged or were completely demolished.

This fast rate of destruction led to a combined archaeological investigation of the remaining kilns, detailed GIS mapping, and excavations (Miksic and Chhay 2010: 11) to establish a site inventory, and recover a considerable amount of ceramics. The GPR survey has supported these efforts to further determine the extent of the archaeological resources, to be able to safeguard the remaining archaeology (Sonnemann and Chhay 2008).

\section{ARCHAEOLOGICAL PROSPECTION AND KILNS}

The potential of non-invasive geophysical research on kilns had initially been demonstrated by magnetometers. Particularly for the detection of ceramic kilns, magnetometry is possibly the most utilized method (Houghton, 1991; Gaffney et al. 2000; Nishimura 2009; Kamei et al. 2000). The technique can identify a kiln, particularly the fire box, due to the strong magnetic anomaly that is produced by the high temperature burning of the kiln. At the time of firing, the temperature is raised above the Curie point of particular clay elements, resetting the magnetization when cooling down. The induced thermoremanent magnetization in the hardened clay walls or remaining ceramic sherds produces a strong magnetic dipole anomaly (Basavaiah 2011: 294).
Since the areas at Bangkong kiln site had been identified previously, ground-penetrating radar (GPR), a well-established technique in archaeological prospection (Conyers 2012; Goodman and Piro 2013), was chosen for this survey to produce further information on the interior. The system consists of a shielded radio antenna that signal into the ground, of which parts are reflected when reaching a feature with different electromagnetic properties (ground composition or condition), until the signal attenuates and disperses. These reflected return signal parts are received by a second antenna and recorded according to time of arrival. When the instrument is moved forward, the combined signal returns produce a vertical image of the subsurface, a radargram.

Particularly the 3-dimensional visualization (Goodman et al. 1995) of parallel running, interpolated GPR profiles is an advantage over other geophysical methods. The combination of horizontal and vertical information into a data cube make it the most versatile technique in archaeological prospection. Successful survey outcome, however, strongly depends on soil composition and condition. At Angkor, GPR has been successfully applied to investigate the depth and extent of channels, and to identify masonry structures and production sites (Sonnemann 2011). Kilns, due to their particular structure and attributes, such as a burned, often collapsed, ware chamber, provide a number of features that should reflect the GPR signal. The technique has been used successfully on kilns in Japan (Goodman et al. 1994; Nishimura 2009).

\section{The Survey at Bangkong}

From the area that was mapped in the GIS survey (Chhay 2009), four kilns were chosen for investigation which were particularly close to the construction area. Each kiln was in a different state of preservation (see Figure 3): BK13, cut off at one side, showed an exposed ware chamber and was used as a reference to evaluate the results of the other kilns. BK12 had been partly destroyed but there was evidence that the ware chamber remained undisturbed. The area of BK14 had been completely bulldozed, so the intention was to search for potential remaining subsurface features. BK26 represented a site where a kiln was expected based on the visible change of soil properties and ceramic distribution (see Table 2) (Sonnemann 2011: 301-303).

While the kilns were made of the same material as the surrounding soil, the burned and hardened clay structure of the kilns was expected to return a strong signal reflection. Based on previous investigations of kiln sites by GPR, this method's potential was to identify and rapidly map the subsurface features of the sites, with intent to measure extent, depth \& possibly the slope of the ware chamber. The survey was performed in December 2008, using a $250 \mathrm{MHz}$ antenna, favouring depth over higher resolution. Five grids were laid out, four covering the complete extent of the kilns using 0.5 $\mathrm{m}$ line spacing and $30 \mathrm{~mm}$ increment, with a signal 

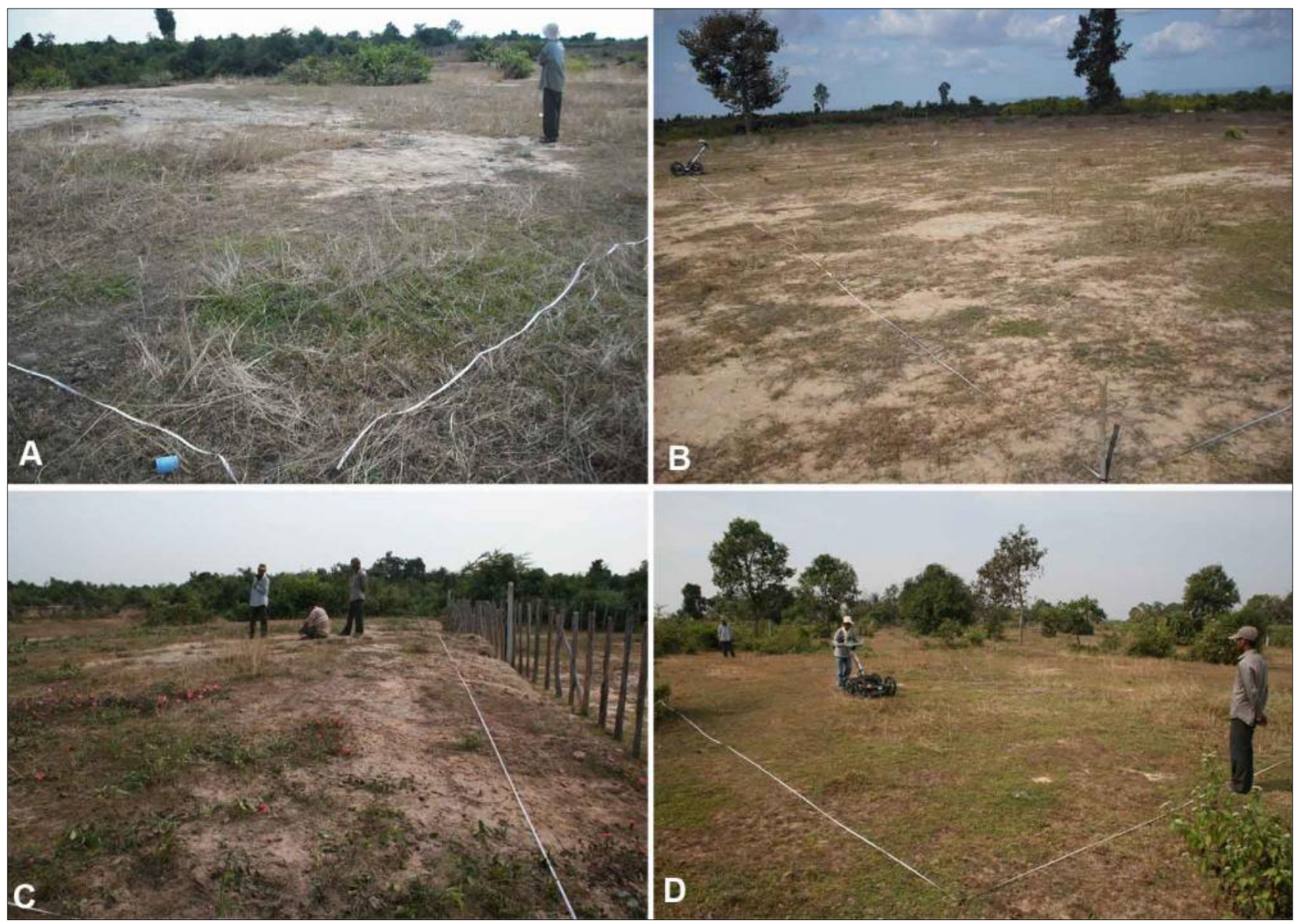

Figure 3: GPR surveys at kiln sites: (A) Area of BK13. (B) Area of BK14. (C) Partly destroyed, and visible transect of kiln of BK12. (D) The area marked as $B K 26$.

Table 2: Surveyed kilns, their state of preservation, as well as archaeological evidence that was found prior to the survey on the surface.

\begin{tabular}{|c|c|c|c|}
\hline No & Potential & Preservation & Visible evidence \\
\hline BK12 & $\begin{array}{l}\text { potential } \\
\text { kiln }\end{array}$ & Partly destroyed & $\begin{array}{l}\text { small pot green } \\
\text { glaze ceramic on } \\
\text { site }\end{array}$ \\
\hline BK13 & kiln visible & Partly destroyed & $\begin{array}{l}\text { top of ware } \\
\text { chamber exposed }\end{array}$ \\
\hline BK14 & $\begin{array}{l}\text { potential } \\
\text { kiln }\end{array}$ & Bulldozed & $\begin{array}{l}\text { only sherds, no } \\
\text { structural evi- } \\
\text { dence on surface }\end{array}$ \\
\hline BK26 & $\begin{array}{l}\text { potential } \\
\text { kiln }\end{array}$ & Undisturbed & $\begin{array}{l}\text { soil change and } \\
\text { quantity of ceram- } \\
\text { ics }\end{array}$ \\
\hline
\end{tabular}

return time of $63 \mathrm{~ns}$, while an additional small grid was laid over the ware chamber of BK13, using $250 \mathrm{~mm}$ line spacing for a more detailed analysis. Migration revealed a mean soil velocity of approximately $0.11 \mathrm{~m} / \mathrm{ns}$. The flat ground surface of the kilns made topographic correction for the interpretation unnecessary.

Before analysing the data, a number of processing steps were applied. A hyperbola fitting estimated a signal velocity of $0.1 \mathrm{~m} / \mathrm{ns}$. The direction of every second radargram was corrected, background noise removed and a manual gain curve applied. The data was sliced in depth slices of about $200 \mathrm{~mm}$, and gridded at $0.1 \mathrm{~m}$ resolution using a $.75 \mathrm{~m}$ search radius.

\section{DISCUSSION}

The processing of the data with the software GPR Slice revealed sizes and structures of several kilns. Strong reflections were associated with the hardened walls of the original kiln mound, as shown in the radargram of BK13 (Figure 4), and visible in the grids as an oval of $15-20 \mathrm{~m}$, as well as a ware chamber of about $6-7 \mathrm{~m}$ length, with the lowest part at about 1500-2000 mm depth. All identified ware chambers are of longitudinal appearance and have similar dimensions (see Figure 5). The structure appears similar to what had been measured by GPR and later been excavated at Tani (Aoyagi et al. 2000). There is no particular orientation of the ware chambers.

\section{Kiln $B K 13$}

Within an area free from vegetation the top of the walls of an open ware chamber were exposed on the surface. Clear evidence of a kiln suited the survey for comparison with the other areas. The GPR survey measured the actual extent of the kiln area (dotted oval). Round features, equally spaced ( $3 \mathrm{~m}$ apart) and of about $1 \mathrm{~m} \mathrm{di}$ - 


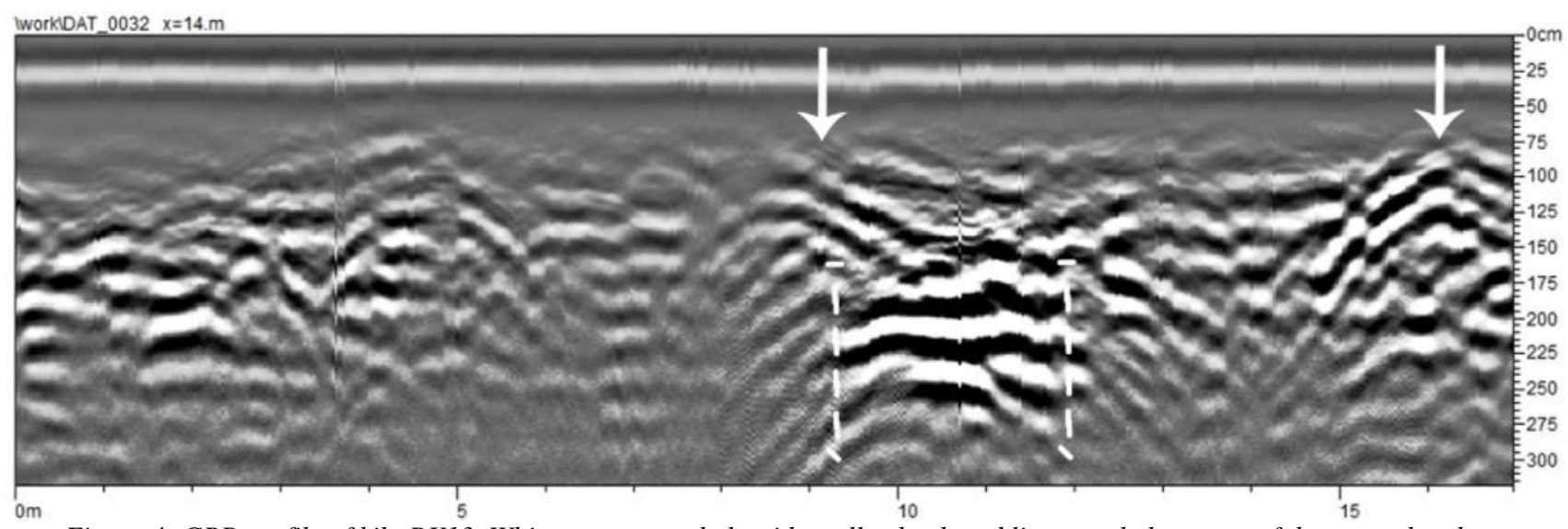

Figure 4: GPR profile of kiln BK13. White arrows mark the side walls, the dotted lines mark the extent of the ware chamber.
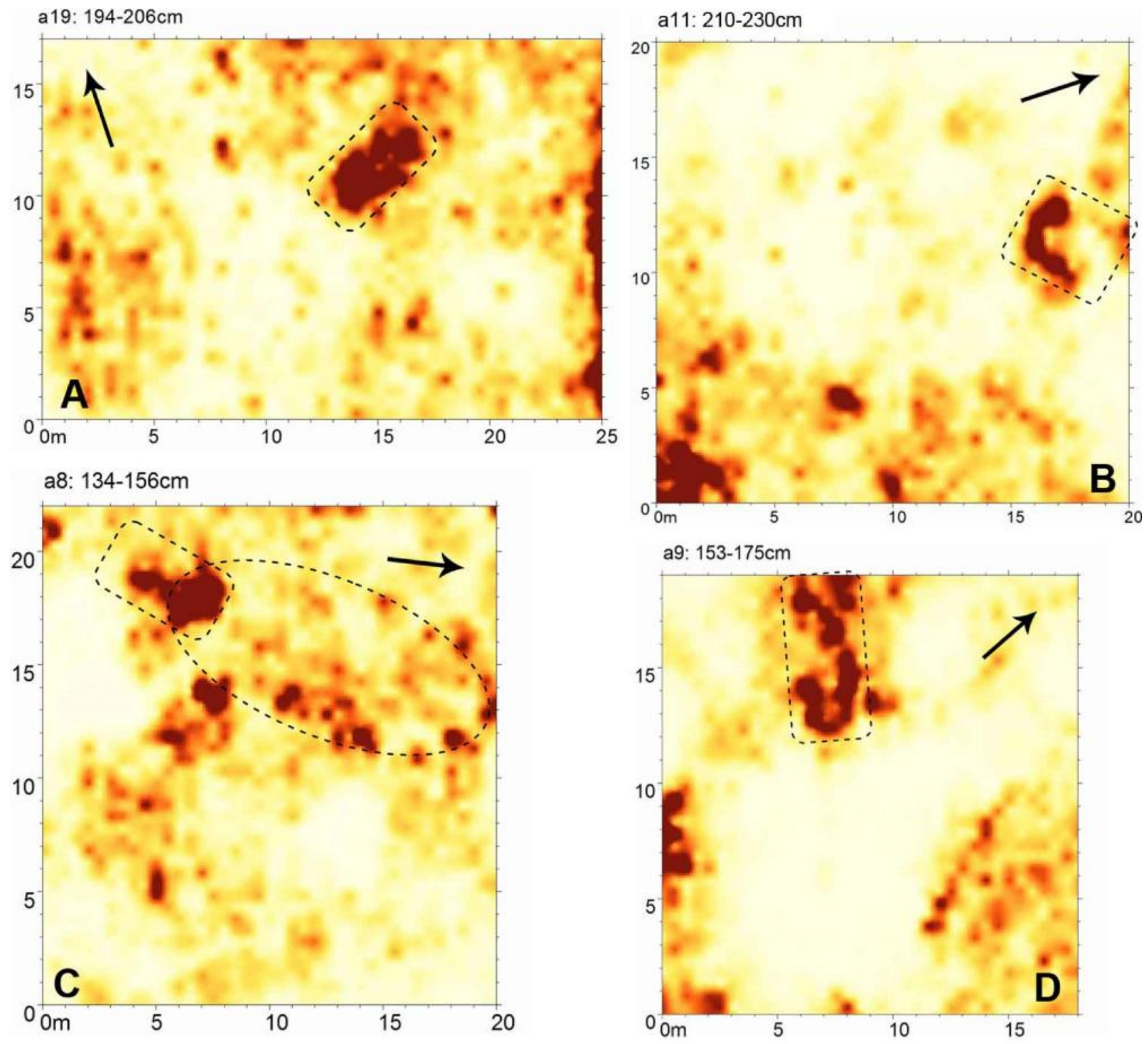

Figure 5: Comparison of the size and state of preservation of the ware chambers (A) BK13, (B), BK14, (C) BK12 (D) BK26 

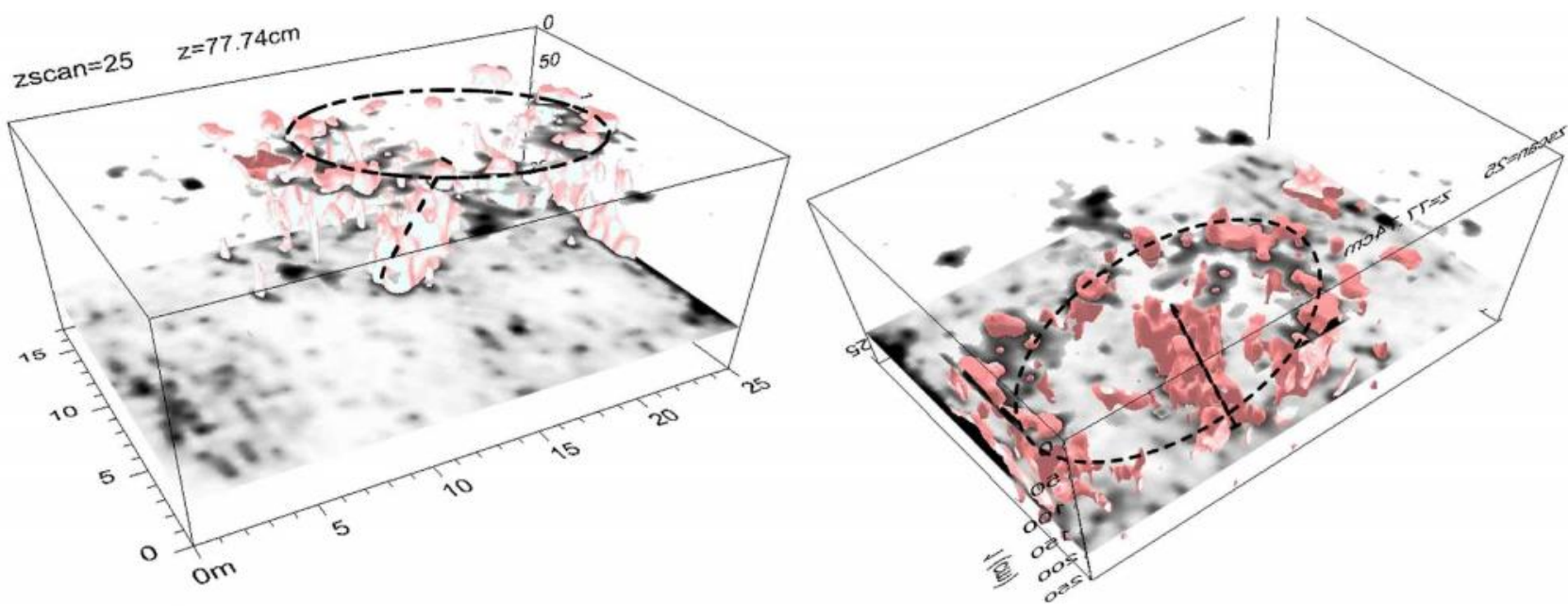

Figure 6: The oval shaped kiln BK13 displayed as iso-surfaces. Marked are the outer walls (dotted oval) and ware chamber (line).

ameter, surround the ware chamber. Those demarcations are only visible in the top meter of the kiln. Additionally, the size $(\sim 5 \mathrm{~m} \mathrm{x} 2 \mathrm{~m})$ and depth $2.25 \mathrm{~m}$ of the ware chamber was mapped, as it is displayed in the isosurface of Figure 6. Strong signal returns resulted from the hardened walls of the kiln, which are interrupted by areas more prone to signal penetration. There was evidence of the fire box as a strong parabola-shaped reflection on the radargram showed on the long side of the mound walls. The slope of the ware chamber was to some extent visible but too difficult to measure precisely, which would have been needed for a comparison with the excavated Tani Kilns.

\section{Kiln $B K 14$}

A change in surface soil colour to a light grey, a small amount of ceramic sherds and less vegetation was the predominant attribute to mark this area as a kiln site. The area had been bulldozed before the survey and showed no structural trace on the surface. The GPR survey detected no clear evidence of a similar ware chamber as in BK 13. However, the northern part of the grid indicates remains of the U-shaped walls of one extent of the ware chamber, which may be part of the oval shaped kiln. The strongest reflection at $2 \mathrm{~m}$ possibly shows the bottom part of the fire box.

\section{Kiln BK12}

This partly destroyed kiln, of which about a quarter had been bulldozed, allowed the investigators to see the profile of the structure, but no evidence of the chamber remained on the surface. The survey showed that the ware chamber to the west, a rectangular feature covering $3 \mathrm{~m} \mathrm{x} 5 \mathrm{~m}$ still existed at least partly. The extent of the kiln is unclear, but some stronger reflections, possibly hardened earthen walls, could define the limit of the clay mound.

\section{Kiln BK26}

A kiln site that is possibly undisturbed was covered with stone rubble at the time of the survey. Nevertheless the signal showed good penetration depth, revealing the approximately $2 \mathrm{~m}$ wide and $5 \mathrm{~m}$ long ware chamber at a depth of $1.8 \mathrm{~m}$ facing northwest. Its $0.5-0.8 \mathrm{~m}$ wide walls are very clearly distinguishable from the interior which appears to have collapsed in the centre. A light reflection defines the complete kiln, of about $11 \mathrm{~m}$ diameter.

Table 3: The potential for kiln investigation by GPR is shown in brief in this table to compare the success at the different sample sites.

\begin{tabular}{lllll}
\hline Kiln & $\begin{array}{l}\text { Extent } \\
\text { of kiln }\end{array}$ & $\begin{array}{l}\text { Ware chamber: } \\
\text { Extent }\end{array}$ & $\begin{array}{l}\text { Fire Box: } \\
\text { Depth }\end{array}$ & $\begin{array}{l}\text { Slope } \\
\text { visible: }\end{array}$ \\
\hline BK12 & $\mathrm{X}$ & $\mathrm{X}$ & $\mathrm{X}$ & - \\
BK13 & $\mathrm{X}$ & $\mathrm{X}$ & $\mathrm{X}$ & $\mathrm{X}$ \\
BK14 & - & - & $\mathrm{X}$ & - \\
BK26 & - & $\mathrm{X}$ & $\mathrm{X}$ & - \\
\hline
\end{tabular}

As the summary of the surveys illustrates (see Table 3 ), none of the surveyed kilns contained the complete combination of features. With some previous idea on what to expect as a result, however, already the first two of four types of evidence, (1) extent of the kiln or (2) ware chamber, (3) depth of fire box, or (3) slope of the ware chamber, could classify an area of ceramic scatter as a former kiln, to mark it for protection or rescue excavation.

The GPR survey has served as an effective, nondestructive technique to investigate these shallow, nonmasonry clay mounds. The technique has presented clear evidence of a potential kiln site that is not easily distinguishable from its surroundings on the surface. In comparison to magnetometer surveys, which can identify the firing chamber, and possibly the ware chamber, the GPR technique has proved successful in clarifying 
the extent of the complete kiln by distinguishing the disturbed earth that covers the ware chamber from its surrounding. When comparing the results with the GPR data from the Tani survey in the 1990s, where the fire box was detected but no wall thickness or slope measured, an expected, but still enormous improvement in detail and visualization can be determined. If the ware chamber of a kiln had remained intact or in existence, its outline, working direction, and depth could be measured. Particularly the 3D visualization of kiln BK 13 shows the possibilities to investigate this type of structure with a non-destructive method, making a complete excavation to determine the size and extent nearly unnecessary. Clear outlines of the chamber walls in all four kilns were determined, easily distinguishable from the sandy soil of the surroundings. The slope however, was only visible in the data of BK 13 . Wherever the dimension of the ware chamber was determined, it showed a length of approx. $5 \mathrm{~m}$, and width of approx. $2 \mathrm{~m}$ as well as walls of $0.5-0.8 \mathrm{~m}$ thickness. These structural attributes were, considering the shallow builtup, similar to the excavated kilns at Tani. With additional knowledge about the interior structure, such as wooden poles supporting the kiln roof as shown in excavations of other kilns (Aoyagi et al. 2000: 235-253; Miksic et al. 2009; Tabata 2008), the probable structure of the Bangkong kilns can be schematically modelled (Figure 7).

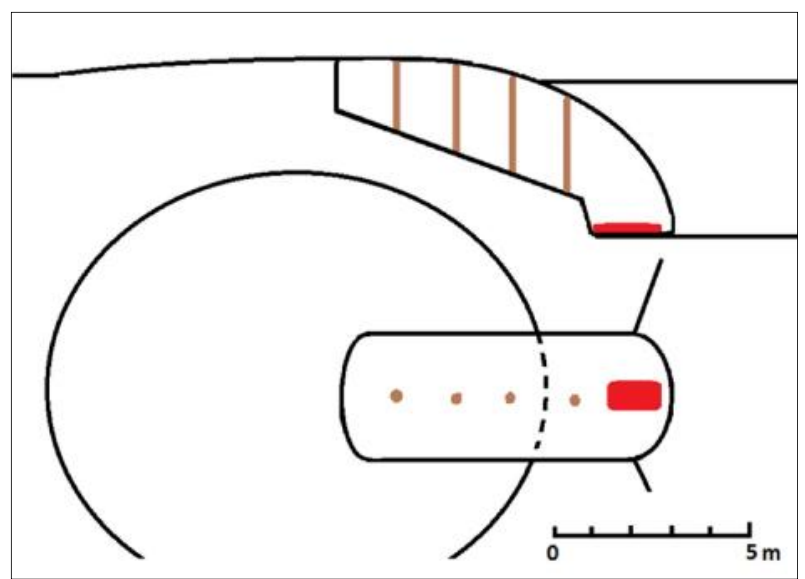

Figure 7: Schematic plan of the kiln type at Bangkong as cross-sectional view (top) and 398 from above (bottom), in accordance to the plans of Tani by Aoyagi et al.. (2000), with the circular mound, the cylindrical ware chamber and the fire box in red.

As often in applied geophysical techniques, the GPR survey was very dependent on the soil composition. Possibly because of the high clay proportion of the soil, the GPR survey could not identify the extent of all four kilns. Most of the area north of the kilns was once covered by rice paddies. The annual flooding in the monsoon of the river may have regularly covered the low mounds with the fertile soil, which becomes hard when it is not exposed to moisture. This cover could have severely attenuated the radio signal (Nakamura 2009:
227), leading to lower signal penetration depth and lesser resolution. However, at Angkor often better signal penetration depth was received in moist environments, where the clayish soil had been waterlogged due to a high groundwater level, or the survey passing a pond or rice-fields, while in dry areas the hardened soil was often impenetrable for the GPR signal. The results of the survey over this very hard and dry soil can therefore be seen as a success.

\section{CONCLUSION}

The survey at the kilns at Bangkong, conducted in combination with field walking and excavation, shows the necessity to improve the safeguarding of non-structural archaeological remains and particularly production sites in Southeast Asia. Since 2009, the construction development has halted in the kiln area, and until now (as of August 2014) no further kiln has been destroyed. Regardless of this, as a result of the combined research a number of kilns were marked as archaeological features in a heritage database to prevent their destruction. With the potential to investigate these kilns further by systematic excavation, the information gained from this type of small area GPR survey helps to define the size of the excavation area, and therefore leaving a smaller archaeological footprint. Testpits will be conducted in November 2014 for a number of Bangkong kilns, including the described ones, to validate their existence.

\section{ACKNOWLEDGMENTS}

The authors would like to thank Prof. Yasushi Nishimura and Nabunken, Japan, for providing magnetometry and GPR data of the Tani kilns to compare it with the Bangkong finds and develop a methodology for Bangkong. The GPR was provided by Dr. Martin Gibbs and the Department of Archaeology at the University of Sydney, the field work was supported by Sydney's Carlyle Greenwell Fund.

\section{REFERENCES}

Aoyagi, Y., Sasaki T., Tanaka, K., Nogami T, Marui M. and T. Sumida 2000. Excavation of a Khmer kiln site: Report of the investigation of Kiln B1, Tani Kiln Complex. UDAYA 1: 235-53.

Aymonier, E. 1901. Le Cambodge - Vol. II - Les Provinces Siamoises. Ernest Leroux. Paris.

Barbetti, M. and D. Hein 1989. Palaeomagnetism and highresolution dating of ceramic kilns in Thailand: A progress report. World Archaeology 21: 51-70.

Basavaiah, N. 2011. Geomagnetism. Solid Earth and Upper Atmosphere Perspectives. Capital Publishing Company. New Delhi.

Brown, R. 1973. The dating and identification of Southeast Asian ceramics. MA Thesis, University of Singapore.

Brown, R. 1977. The ceramics of South-east Asia: their dating and identification. Oxford University Press, Kuala Lumpur. 
Chhay, R. 2009. Preliminary Report of Bangkong Kiln Site BK Site - A case study of Kilns BK12, BK15 and BK16, unpubl. report for APSARA, Siem Reap.

Desbat, A. 2012. Pour une révision de la chronologie des grès Khmers, Aséanie 27: 11-34.

Conyers, L. 2012. Interpreting Ground-penetrating Radar for Archaeology. Left Coast Press, Walnut Creek.

Ea, D. 2010. Angkorian Stoneware Ceramics: The evolution of kiln structure and ceramic typology. Osaka Ohtani University, Osaka.

Hendrickson, M., Pryce, T. O, Sonnemann, T., Phon, K. \& Q. Hua. In press. Industries of Angkor Project, Preliminary investigation of iron production at Boeng Kroam, Preah Khan of Kompong Svay, Siksacakr.

Houghton, A.W.J. 1961. The Roman tilery and brickfield at Ismore Coppice, Wroxeter. Transactions of the Shropshire Archaeological Society 57: 7-12.

Gaffney, C.F., Gater, J.A., Linford, P., Gaffney, V.L. and R. White Large-scale Systematic Fluxgate Gradiometry at the Roman City of Wroxeter. Archaeological Prospection 7: 81-99.

Goodman, D., Nishimura, Y., Uno, T., and T. Yamamoto 1994. A ground radar survey of medieval kiln sites in Suzu City, Western Japan. Archaeometry 36: 317-26.

Goodman, D., Nishimura,Y. and J.D. Rogers 1995. GPR time slices in Archaeological Prospection. Archaeological Prospection 2: 85-89.

Goodman, D. and S. Piro 2013. GPR Remote Sensing in Archaeology. Springer, New York.

Groslier, B. P. 1981. "Introduction to the ceramic wares of Angkor", in: Stock D. (ed.) Khmer Ceramics - 9th to 14th Century. pp. 9-40, Times Printers Sdn. Bhd. Singapore.

Guy, J. 1989. Ceramic Traditions of South-East Asia. Oxford University Press. Singapore.

Jacques C. and M. Freeman 1997. Angkor. Cities and Temples, Thames and Hudson, London.

Kamei, H., Marukawa, Y., Kudo, H., Nishimura, Y., and M. Nakai 2000. Geophysical Survey of Hirui-Otsuka Mounded Tomb in Ogaki, Japan. Archaeological Prospection 7: 225-300.

Miksic J. and R. Chhay 2010. Khmer Potters Emerge from the Shadows: Thnal Mrech and Bangkong Kiln Sites. SPAFA Journal 20: 5-16.

Miksic, J., Chhay, R., Piphal, H., and V. Chhay 2009. Archaeological Report on the Thnal Mrech Kiln Site (TMK 02) Anlong Thom, Phnom Kulen, Cambodia Asia Research Institute Working Paper Series 126, The University of Singapore, Singapore.

Nabunken. 2001. Investigation of the Tani Kiln Site: Geophysical Prospections, Excavations and Site Presentation Proposal", UDAYA 2: 133-40.

Nishimura, Y. 2000 Report of the Kulen Kiln Site Inspection, Report on the Cooperative Research of Asian Cultural Heritage Protection, Nara.

Nishimura, Y. 2009 Campartive geophysical survey results in Japa: Focusing on kiln and building remains. In: Campana, S. and Piro, S.(eds.) Seeing the Unseen. pp. $257-$ 270, Taylor \& Francis Group. London.

Penny, D., Pottier, C., Fletcher, R., Barbetti, M., Fink, D., and Q. Hua 2006. Vegetation and land-use at Angkor, Cam- bodia: a dated pollen sequence from Bakong temple moat. Antiquity 80: 599-614.

Rooney, D. 1984. Khmer Ceramics. Oxford University Press. Oxford.

Silapakorn, K. 1989 Ancient Kiln Sites in Buriram Province. Silapakorn. Bangkok

Sonnemann, T.F. 2011. Angkor Underground - Applying GPR to analyse the diachronic structure of a great urban complex. Unpublished PhD Dissertation, University of Sydney. Sydney.

Sonnemann, T.F. 2012A Inlets and Outlets of the Angkorian baray. Abstract for the 14th EurASEAA, 18-21 Sept., Dublin.

Sonnemann, T.F. 2012B Discovery and Interpretation of a Buried Temple in the Angkor Wat Enclosure. In: M.L. Tjoa-Bonatz, A. Reinecke, and D. Bonatz (eds.) Connecting Empires and States. Selected Papers from the 13th International. Conference of the European Association of Southeast Asian Archaeologists. pp. 226-235, NUS Press, Singapore.

Sonnemann T.F. in press. Geophysical Database Regarding Subsurface Heritage at Angkor, Cambodia. Proc. Of the 41st Annual Conf. of Comp. Appl. and Quantitative Methods in Archaeology (CAA), 25-28 March 2013, Perth.

Sonnemann, T.F. and R. Chhay. 2008. Ground-Penetrating Radar as a Possible Method to Investigate Medieval Khmer Kiln Sites. Abstr. for the Conf. for Anc. Khmer and SE Asian Ceramics: New Archaeological Findings, Production and the Revival of Techniques, Dec. 10-12, 2008. Siem Reap. Cambodia.

Tabata, Y 2007. Preliminary Report of the Excavation of the Anglong Thom Kiln Site, Cambodia. Journal of Southeast Asian Archaeology 27: 63-69.

Tabata, Y. 2008. Some Aspects of the Anglong Thom Kiln, Cambodia. Journal of Southeast Asian Archaeology: 28: 61-74. 